\title{
Assessment of drinking water related to arsenic and salinity hazard in Patuakhali district, Bangladesh
}

\author{
Raman Kumar Biswas ${ }^{1}$, Dhiman Kumer Roy ${ }^{1}$, Abu Reza Md. Towfiqul Islam ${ }^{2}$, \\ Md. Mizanur Rahman ${ }^{3}$, Mir Mohammad Ali ${ }^{4}$ \\ ${ }^{I}$ Faculty of Disaster Management, Patuakhali Science and Technology University, Patuakhali, Bangladesh \\ 2 Department of Disaster Management, Begum Rokeya University, Rangpur, Bangladesh \\ ${ }^{3}$ Assistant Registrar, Patuakhali Science and Technology University, Patuakhali, Bangladesh \\ ${ }^{4}$ Department of Aquaculture, Faculty of Fisheries, Patuakhali Science and Technology University, Patuakhali, Bangladesh \\ *Corresponding author E-mail: gm_towfique_06@yahoo.com
}

\begin{abstract}
The present study was assessed arsenic and salinity hazard of groundwater for drinking purposes in Patuakhali district, Bangladesh. Total 14 deep tube wells were selected randomly for collecting water samples in the study area. $\mathrm{P}^{\mathrm{H}}$, arsenic concentration, salinity and temperature of the water samples were measured by in situ field measurement, HANNA portable arsenic tool box, EC meter and thermometer respectively. The result revealed that the average temperature and $\mathrm{P}^{\mathrm{H}}$ of the study area were $27^{\circ} \mathrm{C}$ and 7.09 shows within the permissible limit according to WHO standard. The EC value was ranged from 520 to $1036.66 \mu \mathrm{S} / \mathrm{cm}$ with an average value of $687.66 \mu \mathrm{S} / \mathrm{cm}$ was falling within the drinking water quality DOE and WHO standard. The TDS values were ranged from 332.8-363.4 mg/l indicates that all the values are within the ranges for drinking purposes. The study was also shown that arsenic of the ground water samples were ranged between 0 to $335 \mathrm{ppb}$ which are within permissible limit according to Bangladesh Arsenic Standard (BAS). Therefore, it can be concluded that the groundwater is slight to moderate suitable for drinking purposes in terms of arsenic and salinity hazards within the acceptable ranges. It is recommended that groundwater of the study area is good for health.
\end{abstract}

Keywords: Salinity Hazard, Suitability, Deep Tube Wells and Drinking Standard.

\section{Introduction}

Water is absolutely the most necessary commodity for the substance and wellbeing for mankind. Most of the available sources of fresh water are lies underground Bangladesh. With the ever increasing demand of water, the importance of utilization of water is increasing at an accelerated rate throughout the world. Arsenic contamination of ground water has appeared to be a serious public health problem in Bangladesh. It has caused increasing concern due to likely health impacts on a large population inhabiting one of the poorest countries of the world; a population which is mostly rural, and whose life style and livelihood are dominated by the influence of water. Information available so far on the magnitude of the arsenic problem in Bangladesh is incomplete. More than $95 \%$ of the total population of Bangladesh now drinks from underground water sources. Test results so far available (through a small proportion of the estimated 10 million tube wells) suggests water contamination above $0.05 \mathrm{mg} /$ liter in the majority of districts, and some samples have ranged up to 10 times this level GOB survey tells that 59 districts of 64 districts are affected by high level of arsenic contamination.

Presently, attention is focused more on deeper aquifers along with surface water which is a source of alternative water options available for safe water for the rural people in Bangladesh. Excessive amount of arsenic in water in Bangladesh are the major problem for drinking purposes. About one-third of wells in Bangladesh are affected by arsenic. Salinity hazard is a problem for the southern part like Patuakhali district. So the arsenic contamination and salinity hazard must be assessed. It is the need for the people of
Patuakhali district. The detail investigation has not been carried out in the study area. But some partial works carried out by [1] Soil and water salinity was reported by the coastal area of Bangladesh [2]. Salinity problems and crop intensification in the coastal regions of Bangladesh was studied in the area [3]. Ahmed et al., [4] investigated the quality of groundwater of Samta village, Sharsha upazila, Jessore district. The quality of groundwater of that area shows partially suitable for drinking purpose and public health; good for irrigation and not suitable for industrial purpose In this regard a research project has been conducted and covered the entire area of Patuakhali district, Bangladesh. It is located between the geographical co-ordinates $22^{\circ} 460^{\prime} \mathrm{N}$ to $21^{\circ} 50^{\prime} \mathrm{N}$ latitude and $90^{\circ} 05^{\prime} \mathrm{E}$ to $90^{\circ} 40^{\prime} \mathrm{E}$ longitude and covers the area of about $3,204.58 \mathrm{~km}^{2}$. The total population is $1,444,340$ and the density of population is $450 \mathrm{~km}^{2}$ [5]. The study area bounded in the North by Barisal district in the East by Vhola district, the west by Barguna district and in the South by Bay of Bengal. The River Kazal, Golachipa and Bishkhali are passing through the study area (Fig. 1). The main objectives of the research work were to assess the groundwater arsenic and salinity hazard and to assess of the nature and extent of the health hazard in the study

\section{Materials and methods}

\subsection{Study design}

Water samples were collected by random sampling in the field. It was decided to collect water samples from deep tube-wells and 
shallow tube wells. These were collected from all over the Districts. Total 14 wells were selected for collecting water samples. Water samples were collected in sterilized plastic bottles from a well only after it has been pumped for some times (Minimum 15 minutes). The bottles were cleaned two times with pumping water before collecting the samples and tightly sealed after collection. For field measurement of $\mathrm{pH}$, a portable $\mathrm{pH}$ meter (HANNA pocket $\mathrm{pH}$ meter) was used. Salinity and temperature of water samples were measured by EC meter and thermometer respectively. Ionic TDS was simply determined by multiplying the measured EC values (in $\mu \mathrm{S} / \mathrm{cm}$ ) by 0.64 as there exists an approximate relation between EC and TDS for most natural water in the range of 100 to $5000 \mu \mathrm{S} / \mathrm{cm}$ leading to the equivalencies $1 \mathrm{meq} / \mathrm{l}$ of cations $=100 \mu \mathrm{S} / \mathrm{cm}$ and $1 \mathrm{meq} / 1=1.56 \mu \mathrm{S} / \mathrm{cm}$ [6]. For determination of
Arsenic concentration HANNA Portable arsenic Tool Box is used during the field work for several days.

\subsection{Laboratory analysis}

All the ground water samples were analyzed in the laboratory again to determine the Salinity range through the measurement of Electric Conductance in $\mu \mathrm{s} / \mathrm{cm}$.

\subsection{Data presentation and interpretation}

The results of chemical analyses of ground water were presented by the program of One-Way ANOVA of SPSS 16.0 version in accordance with the objectives of the study.

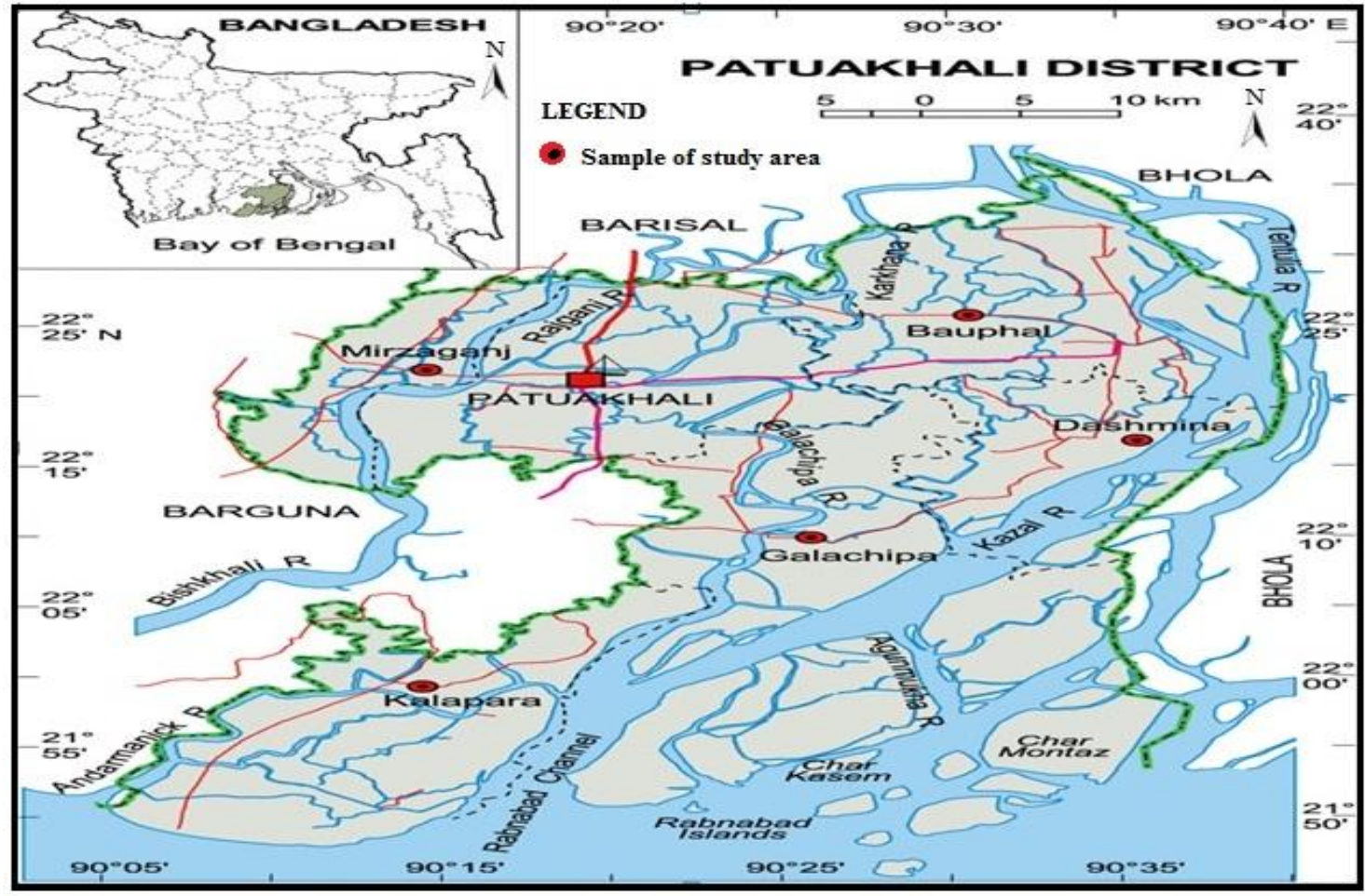

Fig. 1: Map Showing the Study Area Sample Location

Table 1: Physico-Chemical Analysis of the Study Water Samples

\begin{tabular}{|c|c|c|c|c|c|c|}
\hline Location & Depth (m) & Temp $\left({ }^{\circ} \mathrm{c}\right)$ & As (ppb) & $\mathrm{pH}($ Mean \pm st.dav $)$ & $\mathrm{EC} \mu \mathrm{S} / \mathrm{cm}(\mathrm{Mean} \pm \mathrm{st} . \mathrm{dav})$ & TDS mg/l (Mean \pm st.dav) \\
\hline Badarpur,patuakhalisadar & 365 & 27 & 0 & $7.01 \pm 0.1 \mathrm{c}$ & $1036.70 \pm 0.1 \mathrm{a}$ & $663.4 \pm 0.1 \mathrm{a}$ \\
\hline Kalikapur, Patuakhali Sadar & 361 & 26 & 10 & $7.35 \pm 0.1 \mathrm{a}$ & $666.67 \pm 0.01 \mathrm{e}$ & $426.67 \pm 0.01 \mathrm{e}$ \\
\hline Golkhali, Galachipa & 293 & 27 & 10 & $7.05 \pm 0.05 \mathrm{c}$ & $706.6 \pm 0.1 \mathrm{~d}$ & $452.27 \pm 0.1 \mathrm{~d}$ \\
\hline Chiknikandi, Galachipa & 274 & 29 & 10 & $7.2 \pm 0.2 \mathrm{abc}$ & $610.6 \pm 0.0 \mathrm{f}$ & $390.83 \pm 0.0 \mathrm{f} 5$ \\
\hline Alipur, Dashomina & 274 & 28 & 0 & $7.01 \pm 0.1 \mathrm{c}$ & $550.0 \pm 0.2 \mathrm{~h}$ & $352.00 \pm 0.2 \mathrm{~h} 6$ \\
\hline Betagi-shankipura(1),Dashomin & ina 305 & 28 & 0 & $7.15 \pm 0.1 b c$ & $646.6 \pm 0.1 \mathrm{e}$ & $413.87 \pm 0.1 \mathrm{e}$ \\
\hline Betagi-shankipura(2),Dashomin & ina 274 & 27 & 10 & $6.8 \pm 0.2 \mathrm{~d}$ & $623.3 \pm 0.1 f$ & $398.93 \pm 0.1 \mathrm{f} 8$ \\
\hline Baga, Baufal & 299 & 27 & 0 & $7.02 \pm 0.1 \mathrm{c}$ & $656.6 \pm 0.01 \mathrm{e}$ & $420.27 \pm 0.01 \mathrm{e} 9$ \\
\hline Baufal & 244 & 27 & 0 & $7.1 \pm 0.1 b c$ & $520.0 \pm 0.1 \mathrm{i}$ & $332.80 \pm 0.1 \mathrm{i} 10$ \\
\hline Muradia(1), Dumki & 244 & 28 & 0 & $7.29 \pm 0.1 \mathrm{ab}$ & $660.0 \pm 0.1 \mathrm{e}$ & $422.40 \pm 0.1 \mathrm{e} 11$ \\
\hline Muradia(2), Dumki & 259 & 29 & 25 & $6.80 \pm 0.1 \mathrm{~d}$ & $576.6 \pm 0 . \mathrm{g}$ & $369.07 \pm 0 . \mathrm{g} 12$ \\
\hline Angaria, Dumki & 299 & 27 & 0 & $7.27 \pm 0.1 \mathrm{ab}$ & $846.6 \pm 0.2 b$ & $541.8 \pm 0.1 \mathrm{~b} 13$ \\
\hline New Angria High School,Dumk & aki 293 & 27 & 35 & $7.2 \pm 0.1 \mathrm{abc}$ & $813.3 \pm 0.1 \mathrm{c}$ & $520.5 \pm 0.1 \mathrm{c} 14$ \\
\hline Angaria( S.sarker), Dumki & 299 & 27 & 0 & $7.05 \pm 0.1 \mathrm{c}$ & $713.3 \pm 0.1 \mathrm{~d}$ & $456.53 \pm 0.1 \mathrm{~d}$ \\
\hline
\end{tabular}

*The values are calculated as (Mean \pm standard deviation.)

The different alphabets in the rows indicate significant variation (significant $<0.05$ )

\section{Results and Discussion}

Table 1 represents the results of physico-chemical parameters of the drinking water samples of the study area of Patuakhali district, Bangladesh.
Table 1 reveals that the average temperature of drinking water samples of the study area was $27^{\circ} \mathrm{C}$ and in the range of 26 to $29^{\circ} \mathrm{C}$.

The $\mathrm{pH}$ value of drinking water of the study area ranges from 6.7 to 7.38 with an average value of 7.09 which is within the permissible limit for drinking uses [7-8] (Fig. 2). 


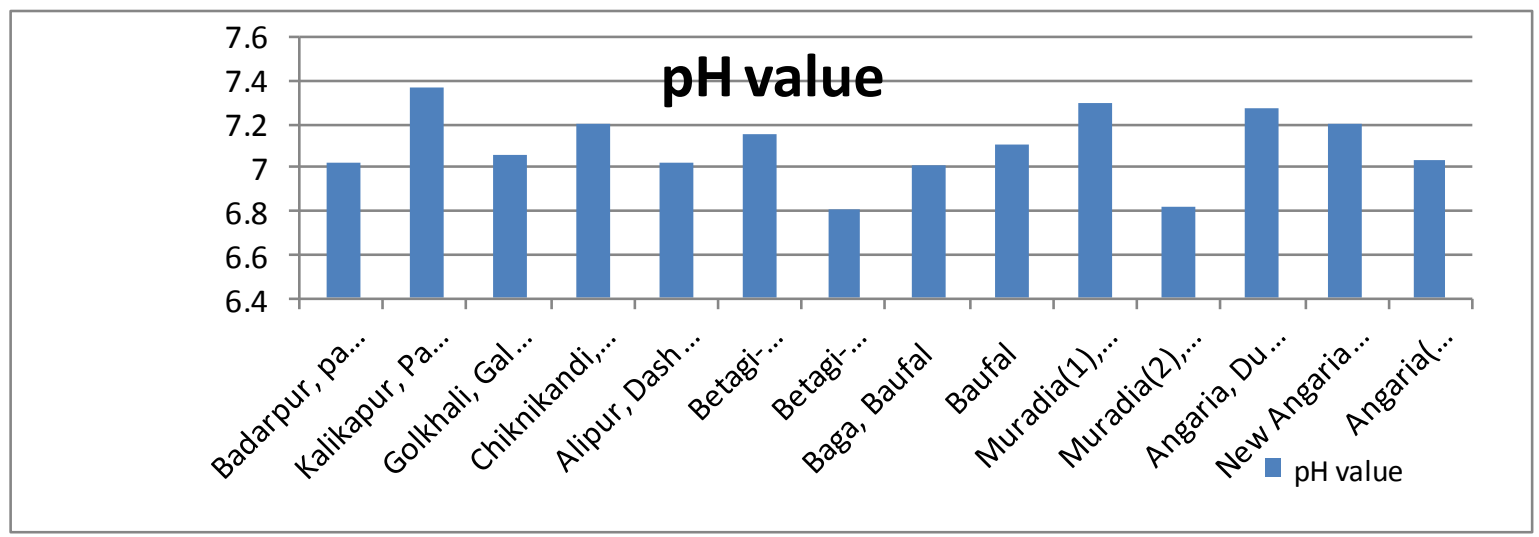

Fig. 2: $\mathrm{P}^{\mathrm{H}}$ Value of Different Locations of Patuakhali District

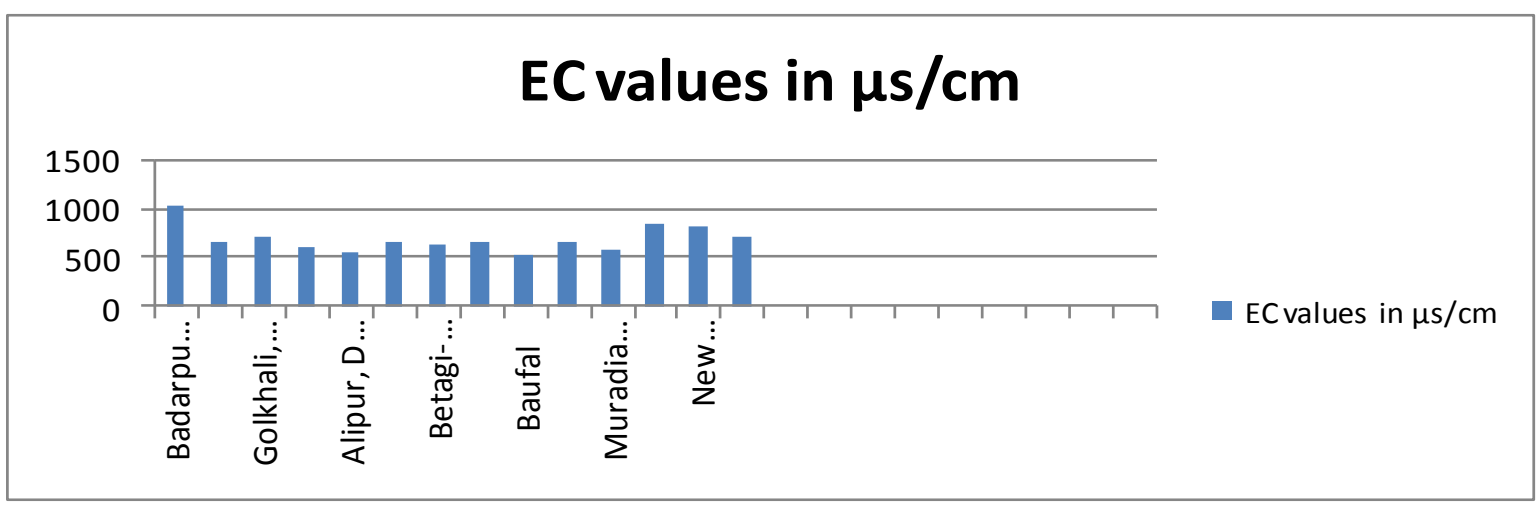

Fig. 3: EC Values of Different Locations of Patuakhali District

\subsection{Salinity measurement}

The EC value of drinking water of the study area ranges from 520 to $1036.66 \mu \mathrm{S} / \mathrm{cm}$ with an average value of $687.66 \mu \mathrm{S} / \mathrm{cm}$ falls within the drinking water quality classification 'Standard'. In terms of agricultural uses the 'degree of restriction on use', EC value of $<700 \mu \mathrm{S} / \mathrm{cm}$ refers the water to 'none'; 700-3000 $\mu \mathrm{S} / \mathrm{cm}$ 'slight to moderate' and $3000 \mu \mathrm{S} / \mathrm{cm}$ 'severe' [9].

Table 2: Electrical Conductance Distribution in Groundwater [10] Water class $\quad$ Specific conductance in $(\mu \mathrm{S} / \mathrm{cm}) \quad$ EC values in $\mu \mathrm{S} / \mathrm{cm}$

\begin{tabular}{lll}
\hline Excellent & $<250$ & \\
Good & $250-750$ & $520-1036.66$ \\
Permissible & $750-2000$ & \\
Doubtful & $2000-3000$ & \\
Unsuitable & $>3000$ & \\
\hline
\end{tabular}

The EC values of ground water of the study area ranges $520 \mu \mathrm{s} / \mathrm{cm}$ in Baufal upazila to $1036.66 \mu \mathrm{S} / \mathrm{cm}$ in Badarpu union of Patuakhali sadar which indicate the ground water of the study are is permissible to drinking purposes (Fig. 3). It is easily presumable from the data in Table 1 that in terms of EC value, the drinking water of the study area is slight to moderate suitable for drinking purposes [10].

In addition to above parameters, it is also important to consider the TDS in water. As EC and TDS values of groundwater are interre- lated, both the values are indicative of saline water in absence of non-ionic dissolved constituents [11]. The TDS values range from $332.8-663.4 \mathrm{mg} / \mathrm{l}[8]$. It indicates that all the values are within the ranges for drinking purposes according to [7-8], [12]. In terms of agricultural uses the 'degree of restriction on use', the TDS values $<450,450-2000$ and $>2000 \mathrm{mg} / \mathrm{l}$ represent the irrigation water as 'none'; 'slight to moderate' and 'severe', respectively (Table 2). So, like EC, the irrigation water of the study area is 'slight to moderate' category for irrigation purpose.

\subsection{Arsenic concentration measurement}

Humans are exposed to arsenic mainly through ingestion and inhalation. The World Health Organization (WHO) has recently revised its original guideline value for arsenic in drinking water of $0.05 \mathrm{mg} / 1$ [8] .The Bangladesh government level is $0.05 \mathrm{mg} / \mathrm{l}$ [7]. Water with high level of arsenic is lead to health problems such as melanosis, leukomelanosis, hyperkeratosis, black foot disease, cardiovascular disease, hepatomegaly, neuropathy and cancer [13] Arsenic tends not to accumulate in the body but is excreted naturally. If ingested more than it can be excreted, arsenic accumulates in the hair and fingernails [13]. The toxicity of arsenic depends on the chemical and physical forms of the compound, the route by which it enters the body, the dose and the duration of exposure, dietary compositions of interacting elements and the age and sex of the exposed individuals. 


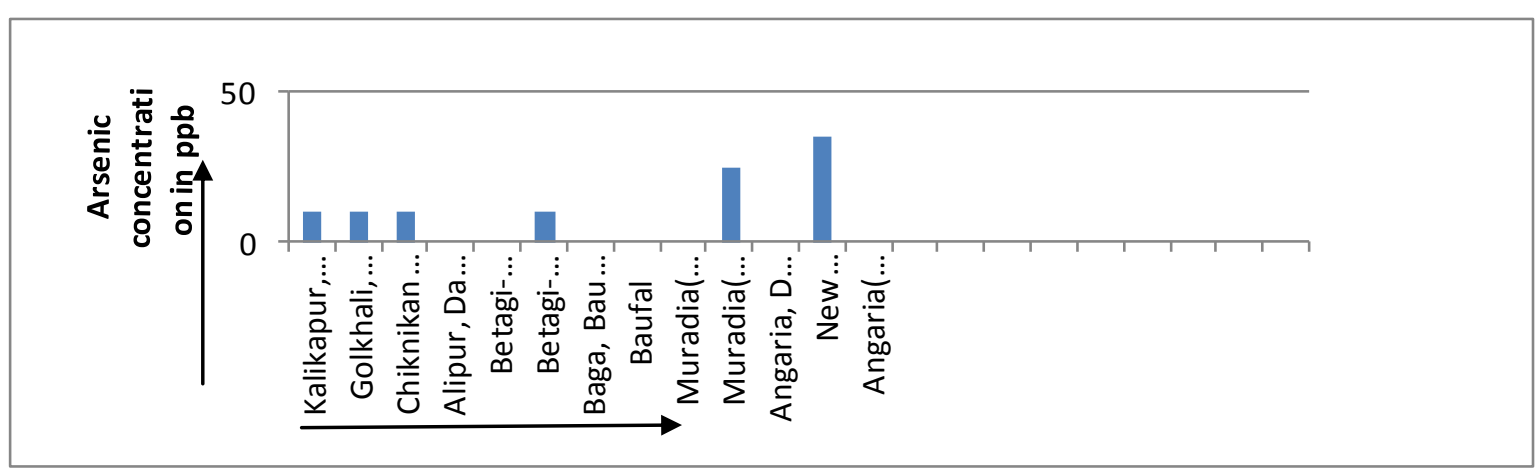

Fig. 4: Arsenic Values of Different Locations of Patuakhali Districts

From the analysis it has been observed that all the ground water samples are in the range between $0 \mathrm{ppb}-335 \mathrm{ppb}$ which are within the range of Bangladesh Arsenic Standard (<50ppb), according to WHO. The highest value of Arsenic concentration is $35 \mathrm{ppb}$ in New Angaria High School under Dukmi upazila (Fig. 4). On the other hand Alipur, Betagi, Baga, Baufal union contains lowest level of Arsenic concentration of $0-10 \mathrm{ppb}$. The common observation in arsenic-affected areas is that the concentration of arsenic in hand tube wells decreases with depth. A large number of deep tube wells were installed by the Government of Bangladesh that had a depth or more than $100 \mathrm{~m}$ to obtain arsenic-safe water in arsenic-affected villages. We have systematically collected water samples from 14 deep tube wells at depth range of 229 to $365 \mathrm{~m}$ from six upazila of Patuakhali district, Bangladesh.

From table 1, it can be seen that arsenic levels of $50 \mathrm{ppb}$ are only always absent in water from hand tube well water deeper than 350 $\mathrm{m}$. From the overall investigation it can be concluded that Arsenic concentration of Patuakhali district is in permissible limit for drinking purposes.

\subsection{Drinking water quality standard}

The drinking water quality standards are those, which all the limitations of water use criteria recommended by world health organization [8] and Bangladesh water pollution control Board [12] which gives the guideline values of chemical constituent in water for drinking standard. The ground water of the study area is compared and correlated with whom and Bangladesh standard for drinking purposes is given in the table 3 . From this table it may be concluded that, all the parameters have been determined systematically are suitable for drinking and health purposes, according to [7-8], [12].

Table 3: Correlation Of the Groundwater Quality Of the Study Area with [7-8], [12] For Drinking Purpose

Water quality WHO standard DOE BWPCB Concentration in study area \begin{tabular}{lllll}
\hline $\mathrm{P}^{\mathrm{H}}$ & $6.5-8.5$ & $6.5-8$ & $6.5-9$ & 6.7 to 7.38
\end{tabular}

Temp $\left({ }^{\circ} \mathrm{C}\right) \quad-\quad 20-30 \quad-\quad 26$ to $29{ }^{\circ} \mathrm{C}$

$\begin{array}{lllll}\text { TDS (mg/l) } & 1000 & 1000 & 1500 & 332.8-663.4\end{array}$

EC $(\mu \mathrm{S} / \mathrm{cm}) 1563 \quad 15632344 \quad 520-1036$

As (ppm) $50 \quad 50 \quad$ - $\quad 0$ - 335

\section{Conclusion}

The present study includes the overall assessment of arsenic and salinity hazard of groundwater for drinking purposes in Patuakhali district. The main objectives of the research work were to assess the groundwater arsenic hazard to assess the groundwater salinity hazard in Patuakhali 14 wells were selected for collecting water samples. The study find that the average temperature of drinking water samples of the study area was $27^{\circ} \mathrm{C}$ and in the range of 26 to $29{ }^{\circ} \mathrm{C}$. The $\mathrm{pH}$ value of drinking water of the study area ranges from 6.7 to 7.38 with an average value of 7.09 , which is within the permissible limit for drinking uses. The $\mathrm{EC}$ value of drinking water of the study area ranges from 520 to $1036.66 \mu \mathrm{S} / \mathrm{cm}$ with an average value of $687.66 \mu \mathrm{S} / \mathrm{cm}$ which fall within the drinking water quality standard. The TDS values range from 332.8$363.4 \mathrm{mg} / 1$ [8]. It indicates that all the values are within the ranges for drinking purposes according to [7-8], [12]. From the analysis it has been observed that all the ground water samples are in the range between $0 \mathrm{ppb}-335 \mathrm{ppb}$ which are within the range of Bangladesh Arsenic Standard ( $<50 \mathrm{ppb}$ ), according to WHO [8]. The highest value of arsenic concentration was found $35 \mathrm{ppb}$ in New Angaria High School under Dukmi upazila. All the parameters have been determined systematically are suitable for drinking and health purposes. So the Groundwater of the study area is slight to moderate suitable for drinking purposes in terms of salinity hazards and arsenic concentration is within the acceptable range. Hence, it can be concluded that groundwater is good for health.

\section{References}

[1] Petersen L and Shireen S (2001), Soil and water salinity in the coastal area of Bangladesh

[2] Haque SA (2006), Salinity Problems and Crop Production in Coastal Region of Bangladesh.

[3] Karim Z, Hussain SG and Ahmed M (1990), Salinity problems and crop intensification in the coastal regions of Bangladesh, Soils publication No. 33. BARC. 17.

[4] Ahmed M and Ahsan M (2001), Salinity constraints and agricultural productivity in coastal saline area of Bangladesh.

[5] BBS (Bangladesh Bureau of Statistics) (2006), Statistical Year Book of Bangladesh. Dhaka, Bangladesh: Bangladesh Bureau of Statistic, Ministry of Planning.

[6] Todd DK (1980), Groundwater Hydrology, $2^{\text {nd }}$ edition, Willy, New York, pp.536.

[7] Department of Environment (DOE) (1997), Bangladesh Drinking water standards; Government of the People's Republic of Bangladesh.

[8] World Health Organization (WHO) (1983), Guidelines for drinking water Quality, Geneva.

[9] University of California Committee of Consultants (UCCC) (1974), Guidelines for Interpretations of water Quality for Irrigation. Technical Bulletin, University of California Committee of Consultants, California, USA, 20-28.

[10]Wilcox LV (1955), Classification and use of Irrigation Water, U.S. Dept. of Agriculture, Washington D.C. 19

[11]Michael AM (1992), Irrigation Theory and Practices, Vikash Publishing House Pvt. Ltd., New Delhi, India. 686- 740.

[12]Bangladesh water pollution Control Bddra5(BWPCB) (1976), Water Quality Standard in Bangladesh: Govt. of the People's Republic of Bangladesh.

[13] Khan AR and Ahmed AH (1997), Contamination of groundwater in the selected region of Bangladesh, Journal of Hydrology, 1(2), 20-27. 